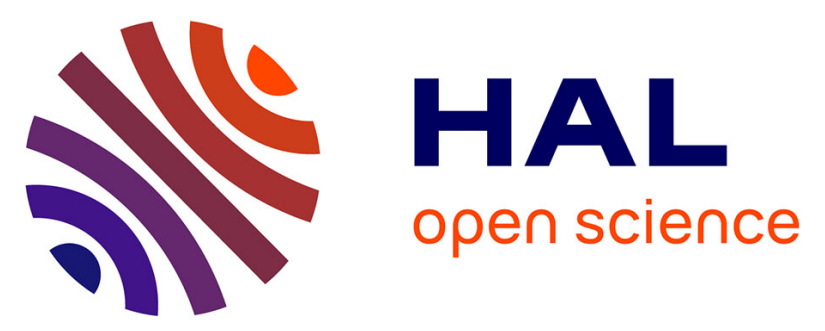

\title{
Sexual Reproduction of Hippospongia communis (Lamarck, 1814) (Dictyoceratida, Demospongiae): comparison of two populations living under contrasted environmental conditions.
}

Zarrouk Souad, Alexander Ereskovsky, Karim Ben Mustapha, Amor El Abed, Thierry Perez

\section{To cite this version:}

Zarrouk Souad, Alexander Ereskovsky, Karim Ben Mustapha, Amor El Abed, Thierry Perez. Sexual Reproduction of Hippospongia communis (Lamarck, 1814) (Dictyoceratida, Demospongiae): comparison of two populations living under contrasted environmental conditions. . Marine Ecology, 2013, 34, pp.432-442. 10.1111/maec.12043 . hal-01456660

\author{
HAL Id: hal-01456660 \\ https://hal.science/hal-01456660
}

Submitted on 13 Apr 2018

HAL is a multi-disciplinary open access archive for the deposit and dissemination of scientific research documents, whether they are published or not. The documents may come from teaching and research institutions in France or abroad, or from public or private research centers.
L'archive ouverte pluridisciplinaire HAL, est destinée au dépôt et à la diffusion de documents scientifiques de niveau recherche, publiés ou non, émanant des établissements d'enseignement et de recherche français ou étrangers, des laboratoires publics ou privés. 
ORIGINAL ARTICLE

\title{
Sexual reproduction of Hippospongia communis (Lamarck, 1814) (Dictyoceratida, Demospongiae): comparison of two populations living under contrasting environmental conditions
}

\author{
Souad Zarrouk ${ }^{1,2}$, Alexander V. Ereskovsky ${ }^{3}$, Karim Ben Mustapha ${ }^{1}$, Amor El Abed ${ }^{2}$ \& Thierry Pérez ${ }^{3}$ \\ 1 Institut National des Sciences et Technologies de la Mer, Salammbô, Tunisia \\ 2 Faculté des Sciences Mathématiques, Physiques et Naturelles de Tunis, Compus Universitaire Tunis El Manar, Université de Tunis El-Manar, \\ Tunis, Tunisia \\ 3 CNRS UMR 7263 IMBE 'Institut Méditerranéen de Biodiversité et d'Ecologie marine et continentale', Station marine d'Endoume, Aix-Marseille \\ Université, Marseille, France
}

Keywords

Mediterranean sea; reproductive cycle; reproductive effort; sponges; temperature; Tunisia.

\section{Correspondence}

Thierry Pérez, Aix-Marseille Université, CNRS UMR 7263 IMBE 'Institut Méditerranéen de Biodiversité et d'Ecologie marine et continentale', Station marine d'Endoume, rue de la Batterie des Lions, 13007-Marseille,

France.

E-mail: thierry.perez@imbe.fr

Accepted: 27 October 2012

doi: 10.1111/maec. 12043

\begin{abstract}
The study of the reproductive processes of benthic invertebrates is essential to the understanding of their population dynamics and is also important in formulating conservation plans, especially for exploited species. The sexual reproduction of Hippospongia communis, the 'honeycomb' bath sponge, was studied at two locations in the Mediterranean Sea: the Kerkennah Islands (Tunisia, South Mediterranean), where the mean annual seawater temperature is $19^{\circ} \mathrm{C}$, and Marseille (France, Northwestern Mediterranean Sea), where the mean annual water temperature is $16^{\circ} \mathrm{C}$. The aim of this comparative study was to determine whether different environmental conditions could affect reproduction patterns. At both locations, H. communis was found to contain sexual reproductive elements year-round. Oogenesis and embryogenesis occurred throughout the year, whereas spermatogenesis occurred during shorter periods between October and November, in both populations. While gametogenesis seemed to be synchronized, indicating that fertilization could occur at the same time at both locations, spawning was observed in late summer in Marseille, whereas it started in late spring for the Kerkennah population. Larval development of H. communis seems to take longer for sponges living at cooler locations such as Marseille. Reproductive effort calculated for both sexes showed significantly higher values for specimens from Kerkennah Islands. By comparing sexual reproductive patterns of populations living in two contrasted environments, we suggest that a change of thermal regime can affect $H$. communis phenology.
\end{abstract}

\section{Introduction}

Hippospongia communis (Lamarck, 1814) is one of the most abundant and widely distributed Mediterranean bath sponges. Being one of the first-grade species, this species has a high commercial value in the world sponge market and is currently mass harvested throughout the Mediterranean Sea. However, the production of Mediterranean sponges has considerably decreased because of the depletion of natural banks, due to both overfishing and devastating epizootic events that occurred during the mid-1980s (Ben Mustapha \& Vacelet 1991; Gaino et al. 1992; Vacelet 1994) 
and then during the late 1990s and early 2000s (Pérez et al. 2000; Garrabou et al. 2009; Lejeusne et al. 2010).

The endangered status of many commercial species has encouraged biological and ecological research on harvested species of mollusks, crustaceans and fishes. Indeed, determining the reproductive processes is a key step towards a better understanding of population dynamics (Reiswig 1973; Ayling 1980; Fell 1983; Maldonado 2006), which can help in designing restoration and conservation plans (Dayton 1979; Kaye \& Reiswig 1991b; Wing et al. 2003; Baldacconi et al. 2007; Gaino et al. 2007). Little is known about the biology of the commercial sponge. Several aspects of the reproduction of a few species from the Spongiidae family were investigated: Spongia officinalis in the Mediterranean Sea (Scalera-Liaci et al. 1971; Gaino et al. 1984; Baldacconi et al. 2007), and some Spongia and Hippospongia species from the Gulf of Mexico and the Caribbean Sea (Storr 1964; Kaye 1991; Kaye \& Reiswig 1991a,b). However, the only available data for H. communis comes from very early studies undertaken in Tunisia (Allemand-Martin 1906; Tuzet \& Pavans de Ceccatty 1958).

The morphology, reproduction biology and development of marine organisms can be influenced by environmental features such as substrate, light, salinity, water motion, nutrients and temperature (Dayton et al. 1998). Temperature is generally considered to be the most important factor affecting distribution, metabolic processes, and life cycle events of marine organisms (Kinne 1970; Bhaud et al. 1995; Riesgo \& Maldonado 2008). Sponge phenology may be influenced by environmental factors and especially by seawater temperature (Lévi 1956; Fell 1974; Reiswig 1983; Simpson 1984; Sarà 1992; Maldonado \& Riesgo 2008). As in a large number of organisms, temperature is frequently assumed to be involved in the regulation of sponge reproduction (Fell 1974; Ayling 1980; Witte \& Barthel 1994; Fromont 1999). A relationship between periods of initiation of gametogenesis, embryonic development and spawning on the one hand and seasonal variations of seawater temperature on the other has been suggested in a number of studies on sponges from different regions (Storr 1964; Kaye \& Reiswig 1991a; Fromont 1999; Ereskovsky 2000; MerozFine et al. 2005; Ettinger-Epstein et al. 2007; Gerasimova \& Ereskovsky 2007; Mercurio et al. 2007; Riesgo et al. 2007; Whalan et al. 2007a; Maldonado \& Riesgo 2009; Gaino et al. 2010; Leong \& Pawlik 2011).

In this study, we aimed at determining the reproductive features of two populations of Hippospongia communis living in contrasted areas of the Mediterranean Sea: one from Kerkennah Islands in Southern Tunisia and the other from Marseille on the French Mediterranean coast. The two sites considered in this study case contrast by their geography but also by the habitat where $H$. communis can be found. The Tunisian sponges are abundant in very shallow Posidonia oceanica beds, whereas the French sponges are usually less abundant and inhabit the entrance of underwater caves. In these two sites, sponges are exposed to very contrasted temperature regimes, the annual mean temperatures being respectively $19{ }^{\circ} \mathrm{C}$ with a rather high variability (about $20^{\circ} \mathrm{C}$ of difference between minimal and maximal values) in Kerkennah and $16{ }^{\circ} \mathrm{C}$ with moderate variability (about $10{ }^{\circ} \mathrm{C}$ of difference between minimal and maximal values) in Marseille. Through the comparative study of the reproductive traits of these two $H$. communis populations from the south and north of the Mediterranean Sea, we thus aimed at determining the putative influence of the temperature regime on these commercial sponges life cycle and reproductive effort.

\section{Material and methods}

Sampling and environmental data acquisition could not always be conducted in exactly the same way at both stations due to logistics, but sample treatment and data analysis were performed exactly the same.

\section{Studied species}

Hippospongia communis (Lamarck, 1814) (Demospongiae, Dictyoceratida, Spongiidae), also called the 'honeycomb' sponge, is the most widely exploited species in the Mediterranean Sea. Hippospongia communis collected in Kerkennah shallow waters are massive and globular in shape (diameter between 20 and $45 \mathrm{~cm}$ ). They grow on the rhizomes of Posidonia oceanica. Their color surface is blackish-grey, paler when shaded, and the interior is generally cream-colored to orange. The basal part of most of specimens is rust-like, a color resulting from the occurrence of lepidocrocite granules inside the spongine fibers (Vacelet et al. 1988; Cook \& Bergquist 1999). The surface is irregular conulose. The numerous oscules are usually large but show high variability from 2 to $7 \mathrm{~mm}$. The body of the sponge is also traversed by wide canals, often attaining more than $2 \mathrm{~cm}$ in diameter. The consistency is firm and elastic. Specimens collected in Marseille were usually smaller, with diameters never exceeding $20 \mathrm{~cm}$. They generally grew at the entrance of underwater caves or in coralligenous formations, from 10 to $25 \mathrm{~m}$ depth. There, the surface of the sponge is often covered by epibiotic sponges such as Crella pulvinar or Pleraplysilla spinifera.

\section{Study area}

Kerkennah Islands are a group of islands lying off the east coast of Tunisia in the Gulf of Gabes (Fig. 1). The islands 
are surrounded by shallow waters (maximum depth $5 \mathrm{~m}$ ). This area is characterized by dense Posidonia oceanica meadows. The Posidonia beds are often crossed by tide channels that are occupied by Caulerpa prolifera. In this site, the seawater temperature was recorded with thermometer twice each sampling day of the study period. The annual average temperature in the Kerkennah islands was $19.3^{\circ} \mathrm{C}$, the warmest period of the year extending from May to October. The maximum is recorded in July and August with more than $30^{\circ} \mathrm{C}$, and the minimum occurs in January $\left(12^{\circ} \mathrm{C}\right)$.

In the Marseille area, sampling was performed at Plane Island at the entrance of an underwater cave called 'Grotte à Roro' (Fig. 1). There, H. communis is concentrated at $15 \mathrm{~m}$ depth. In this area, the impact of recent climatic events on marine biodiversity has motivated the implementation of an intensive monitoring of the thermal regime (see for instance Bensoussan et al. 2010; Crisci et al. 2011). The seawater temperature is recorded throughout the year at high frequency (one recording every $2 \mathrm{~h}$ ) with permanent data loggers (Onset Tidbit; MedChange Programme). Seawater temperature is highly variable year-round, even during the summer season. The annual average temperature is $16.2^{\circ} \mathrm{C}$, with the minimum values being generally recorded in January $\left(13{ }^{\circ} \mathrm{C}\right)$ and the maximum values at the end of the summer $\left(23.5{ }^{\circ} \mathrm{C}\right.$ during the study period).

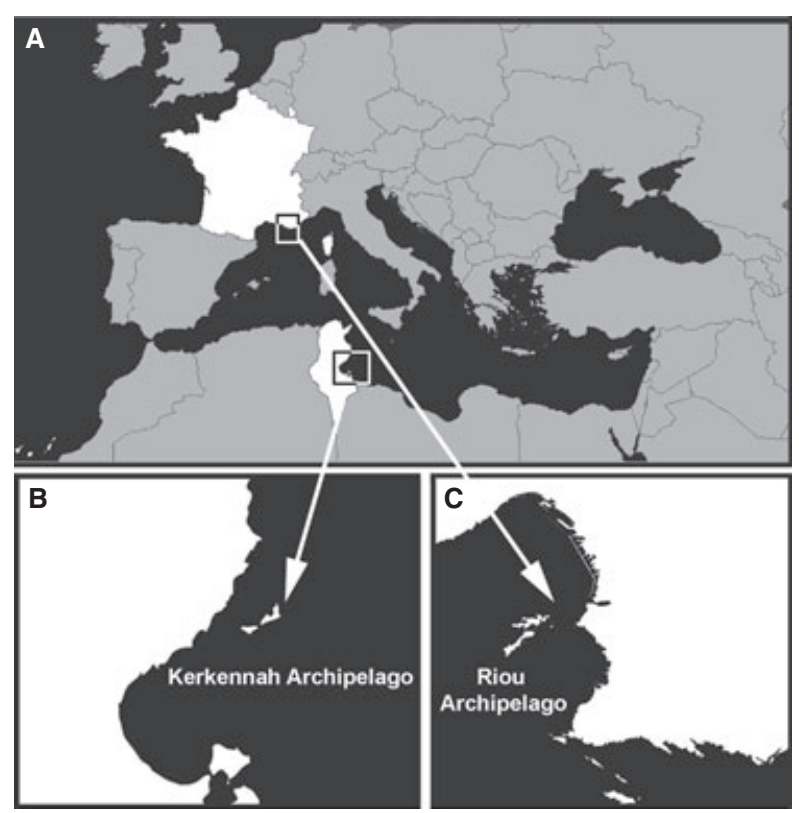

Fig. 1. Geographical location of the study area (A) Mediterranean Sea, (B) Tunisian coast: Kerkennah Islands, (C) French coast: Marseille, Plane Island.
Collection and morphological analysis of samples

To characterize the life cycle and assess the reproductive effort, sponge samples were collected monthly and randomly from the two studied areas. Small pieces of approximately $1 \mathrm{~cm}^{3}$ were cut in the basal, central and surface choanoderm of each sponge, in order to properly estimate the reproduction effort (RE). Because of the elastic consistency of Hippospongia communis, the fragments were excised using a sharp scalpel to avoid damaging the cell structure. The reproductive elements were observed using light microscopy.

In Kerkennah, sponges were collected monthly at 1-2 $\mathrm{m}$ depth, using a spear or by skin-diving, over a period of 2 years from October 2005 to September 2007. The individuals sampled all had a diameter between 20 and $25 \mathrm{~cm}$. At each sampling date, a minimum of six individuals was collected. A total of 150 individuals (68 in 2005-2006 and 82 in 2006-2007) were collected in Kerkennah. In Marseille, six to 10 sponges were sampled monthly by SCUBA diving over 1 year (2008). Because of bad weather conditions, no samples were obtained in November, December or February. A total of 59 individuals were sampled, all with a diameter close to $20 \mathrm{~cm}$.

Soon after collection, samples were processed following the method of Pérez et al. (2011). The small sponge fragments were fixed in Bouin liquid (71\% of saturated picric acid, $24 \%$ of pure formalin and $5 \%$ of pure acetic acid) Samples were then thoroughly washed, dehydrated through an ethanol series, and embedded in paraffin. Serial sections of $8 \mu \mathrm{m}$ thickness were mounted on glass slides and stained with Trichrome of Masson and Goldner hematoxylin. Each section was then observed under a WILD M20 light microscope, the use of serial sections allowing a good assessment of the shape and the size of each reproductive element, and a precise evaluation of the reproductive effort.

\section{Quantifying the reproductive effort}

The reproductive effort (RE) was worked out on serial sections and expressed as a percentage of the fertile sponge tissues by relating the surface of the reproductive elements to the total area of the sponge section. To obtain an accurate estimation of the RE, about 40 serial sections distributed on four glass slides were analysed for each specimen. Each section was recorded with a digital camera mounted onto a Leica DMLB light microscope, through the image capture system Evolution LC color. For the calculations of female RE, we considered oocytes, eggs, embryos and larvae. For the calculation of male RE, we considered spermatic cysts. The RE was calculated by measuring, for each section, the surface of all the 
reproductive elements related to the total surface of the section. For each individual, the RE indicated is thus the mean of 40 calculations. IMAGEJ software (http://rsb. info.nih.gov/ij/index.htmL) was used to measure the surface area of each reproductive element.

\section{Results}

\section{Reproduction features}

Hippospongia communis is ovoviviparous. Male and female reproductive elements were never observed in the same specimen in the two populations. Only $9 \%$ of males and $75 \%$ of females were found among the reproductive specimens in Kerkennah, as opposed to $5 \%$ of males and $49 \%$ of females in Marseille. Specimens without reproductive elements were therefore $16 \%$ and $46 \%$, respectively, in Kerkennah and in Marseille. Sex ratios (male:female) recorded were 1:8 in Kerkennah and about 1:10 in Marseille (Fig. 2).

Spermatogenesis occurs in spermatic cysts throughout the mesohyl (Fig. 3A). Spermatic cysts derive from the transformation of choanocyte chambers. Spermatogenesis is considered to be the cause of an important mesohyl disruption. During the process of choanocyte chamber transformation marked by an increase in diameter of the spermatic cysts, the surrounding cells become flat and more elongate. Spermatic cysts are spherical, their diameters increasing progressively in size from $34.87 \pm 2.37$ to $65.34 \pm 3.97 \mu \mathrm{m}$. Their development is asynchronous within individuals, but spermatocyte differentiation is synchronous within one spermatic cyst (Fig. 3A,B). The initial stage of spermatogenesis is characterized by large spermatogonies that fill up small cysts. When they develop, spermatocytes diminish in size, become denser and turn into spermatids and, finally, mature spermatozoa.

Oogenesis occurs in the mesohyl as well. Early oocytes are scattered ameboid-like or spherical cells, displaying a large nucleolated nucleus (Fig. 3C). During vitellogenesis, oocytes increase significantly in size from 35 to $200 \mu \mathrm{m}$ because of an accumulation of phagosomes and yolk granules in their cytoplasm. A layer of nurse-like cells usually surrounds advanced stage oocytes.

Mature oocytes are isolecithal and rich in yolk inclusions. They are oval and surrounded by several layers of

Fig. 2. Monitoring of the reproductive status within the Hippospongia communis populations of (A) Marseille and (B) Kerkennah.
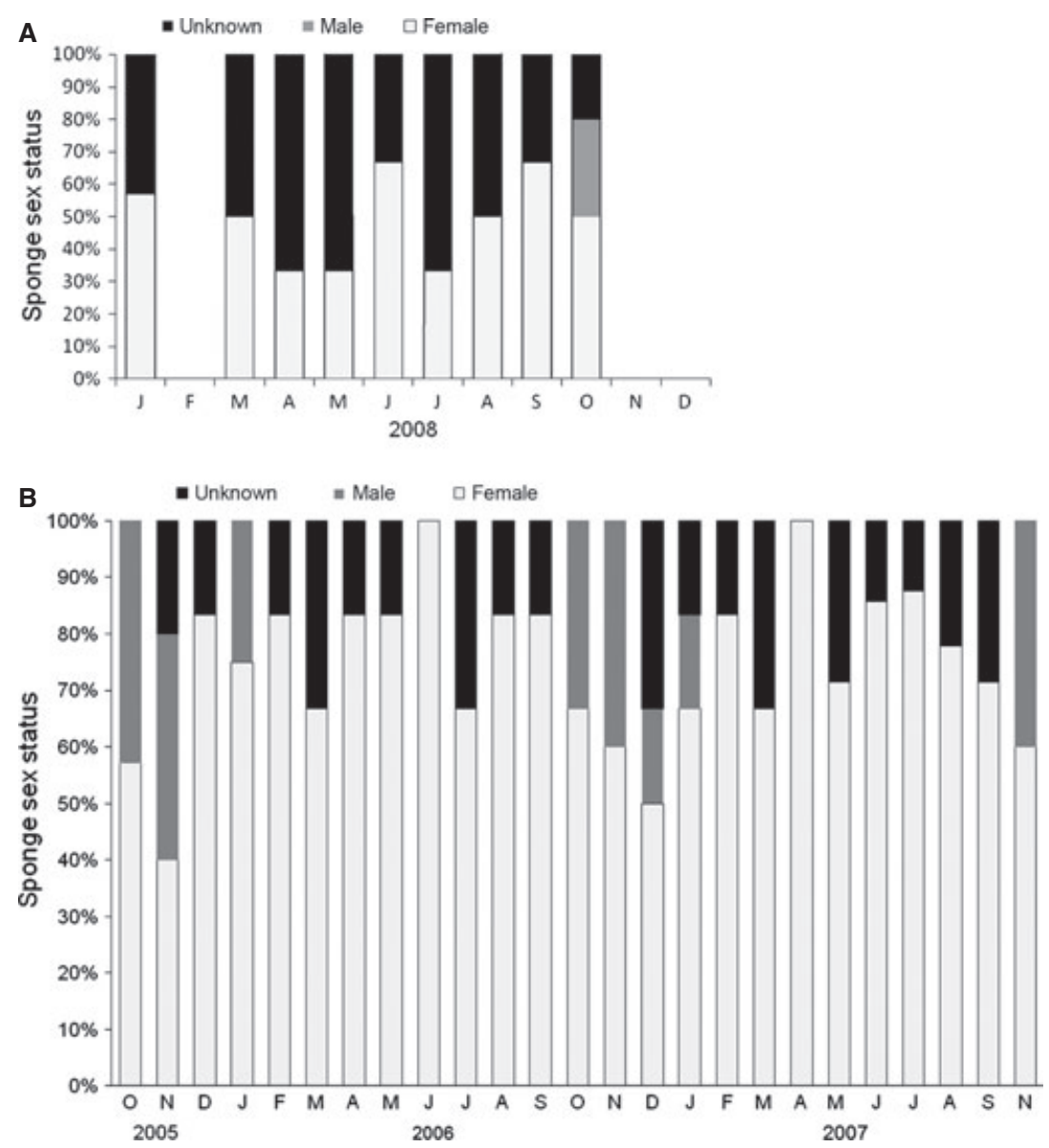

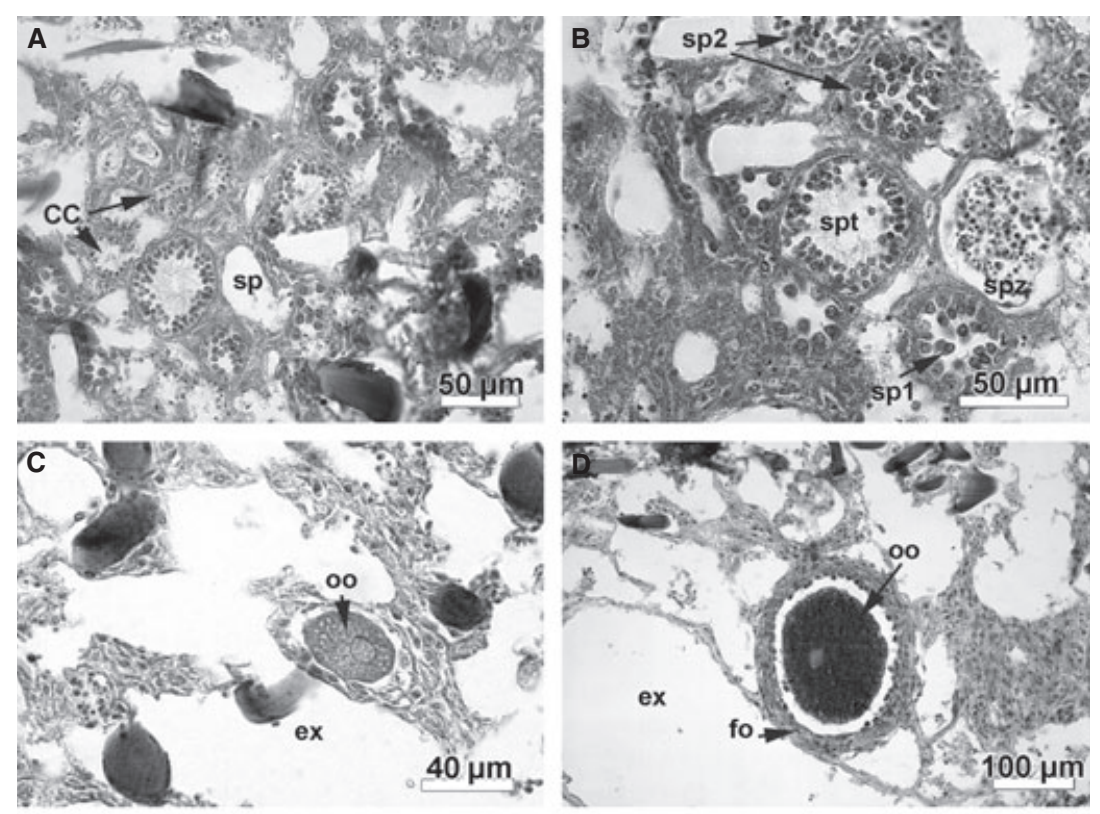

Fig. 3. Histological illustrations of spermatogenesis (A, B), oogenesis (C D) and embryogenesis $(\mathrm{E}, \mathrm{F})$ in Hippospongia communis. (A) Micrograph of male sponge with spermatocysts (sp) in the choanosome. (B) Asynchronous differentiation of male
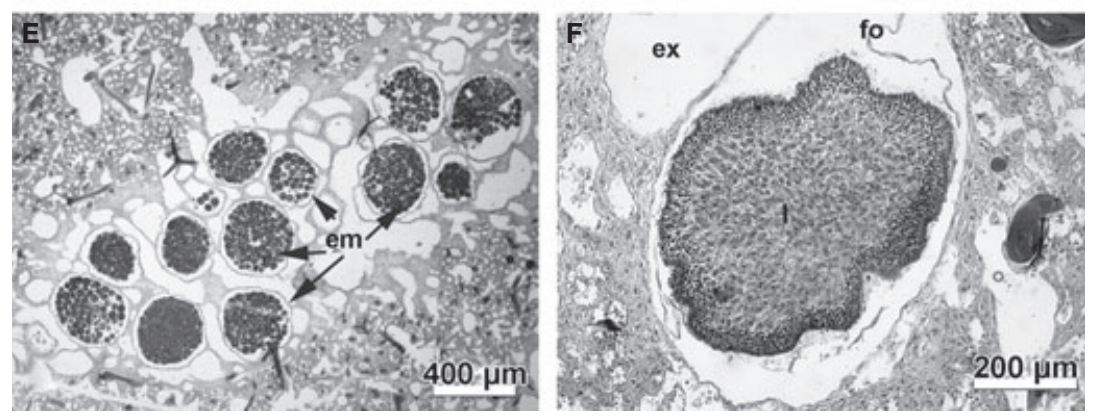
sexual cells within different spermatocysts. (C) Micrographs of young oocyte (oo) in the mesohyl. (D) Micrographs of mature oocytes. Mature oocyte or egg in a multilayer follicule (fo). (E) Micrographs of embryo (em) cluster at the morula stage. (F) Micrographs of parenchymella larva (I) in the sponge mesohyl. c, choanocyte chambers; ex, exhalant canal; I, larva; em, embryos; fo, follicle; oo, oocytes; sp, spermatocysts; sp1, spermatocytes 1; sp2, spermatocytes 2; spt, spermatids; sz, spermatozoa.

follicular cells (Fig. 3D). Eggs and embryos are concentrated in clusters of approximately 6 to 15 elements in brood chambers (Fig. 3E). In some individuals the number of eggs or embryos may exceed 20 within one brood chamber. Mature eggs and embryos measure 300-400 $\mu \mathrm{m}$ in diameter.

The cleavage of the egg is total, equal and chaotic. It leads first to the formation of a morula measuring about $350 \mu \mathrm{m}$ in diameter and made of blastomeres equal in size. Cleavage is asynchronous within the same individual. Embryos are surrounded by a single layer of flattened cells, here considered the follicle (Fig. 3E). The larva is a typical ciliated parenchymella, prolate spheroid with a band of long cilia around the posterior pole (Fig. 3F). Eggs, embryos and larvae are always located near big exhalant canals (Fig. 3C, $\mathrm{D}, \mathrm{F})$. The observed parenchymella larvae of both populations had an average size of $446.58 \pm 22.37 \mu \mathrm{m}$.

\section{Reproductive cycle}

Both at Kerkennah and Marseille, there were always some sexual elements (spermatic cysts, oocytes, embryos or larvae) observed throughout the year (Fig. 4). However, the two populations always presented some individuals that were not involved in reproduction. In males, spermatogenesis started in October in both investigated regions and continued until November at least in individuals collected at Kerkennah Islands (Fig. 4). Because of the lack of samples from Marseille in November, the synchronization of the spermatogenesis between the two regions cannot be confirmed.

In females, oogenesis occurred from March to November at Kerkennah and until at least October in Marseille. In sponges from Kerkennah, early oocytes and larvae can be observed within the same individual in April, May and June, whereas in sponges from Marseille different development stages in a given individual were only observed in July.

There was synchronization between sexes in October and November, so we can assume that fertilization occurred during this period as well in the two populations. The first stages of embryogenesis occurred between October and November. Because of the lack of samples in November and December, we could only observe the first 
Fig. 4. Reproductive cycle of $H$. communis at the two locations: (A) Kerkennah, (B) Marseille.
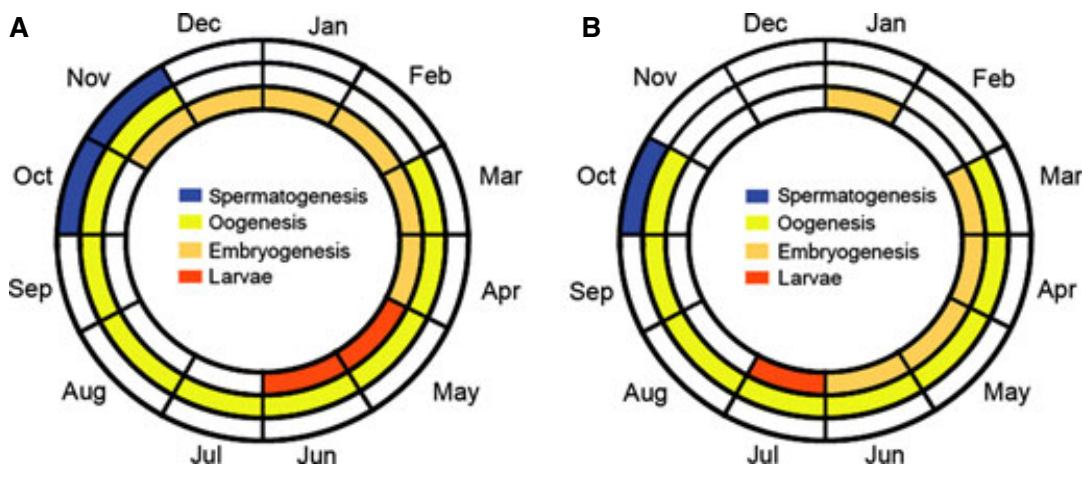

embryos in sponges from Marseille in January. The end of embryogenesis and the last larvae were observed in May-June in sponges from Kerkennah, and in July in sponges from Marseille. Neither embryos nor larvae were detected after June at Kerkennah and after July in the Marseille populations. The fact that young oocytes can also be observed during this period indicates that oogenesis can start before the end of the embryogenesis initiated in October and November the year before.

\section{Reproductive effort}

In male sponges from Kerkennah, there is a rather high reproductive effort (RE) with a maximum in November (21.8 $\pm 4.4 \%$; Fig. 5). Although we were unable to obtain samples for this period of maximum RE in Marseille, we noted that in October the male RE was significantly lower than at Kerkennah: $0.99 \pm 0.2 \%$ in October 2008 in sponges from Marseille as opposed to $12.5 \%$ in October 2005 and 5.0\% in October 2006 in sponges from Kerkennah (Fig. 5).

Except after the period of larval release (summer months), there was no significant variation in time of the female RE between the two populations of $H$. communis. At Kerkennah, female RE ranged between 0.5 and $1 \%$ during the summer months to 7 and $8 \%$ the rest of the year. In Marseille, the minimum RE for females was observed in August $(0.8 \%)$ after larval release and the maximum in June $(3.2 \%)$ at the end of embryogenesis. Regarding the mean annual RE for females, there is no significant difference between years for sponges from Kerkennah, whereas there is a highly significant difference between sponges from Kerkennah $(4.8 \%)$ and from Marseille (2.1\%; Fig. 6).

\section{Discussion}

Our study could not confirm the earlier work on the reproduction of Hippospongia communis suggesting that this species is gonochoric (Tuzet \& Pavans de Ceccatty
1958). Although a rare phenomenon, successive hermaphroditism was observed in tagged individuals of another Mediterranean Spongiidae, Spongia officinalis (Baldacconi et al. 2007). Therefore, successive hermaphroditism cannot be ruled out in $H$. communis since we did not always survey the same individuals during our study.

In sponges, sex ratios can range from 1:1 to strongly biased ratios (Fell 1974; Sarà 1992; Kaye \& Reiswig 1991a,b). In our studied populations of $H$. communis, we found a sex ratio biased towards females (8:1 and 10:1, respectively, for Kerkennah and Marseille populations), whereas previous works on other Spongiidae showed sex ratios varying from male-biased 2.5:1 in Rhopaloeides odorabile (Whalan et al. 2007a) to 1:1 in Spongia officinalis (Baldacconi et al. 2007). Sex ratios therefore seem to differ significantly even in phylogenetically closely related sponge species.

The general patterns of gametogenesis and embryonic development in $H$. communis were similar to those reported from other Dictyoceratida (Scalera-Liaci et al. 1971; Hoppe 1988; Kaye \& Reiswig 1991a; b; Baldacconi et al. 2007; Whalan et al. 2007a; Chung et al. 2010; Ereskovsky 2010). As suggested by previous studies, it seems that spermatogenesis consists in the transformation of choanocytes into spermatocytes, and of choanocyte chambers into spermatic cysts which are widespread throughout the choanosome (Tuzet \& Pavans de Ceccatty 1958; Gaino et al. 1984). Oogenesis is the differentiation of oocytes into mature eggs and their growth by vitellus accumulation. In our study, we could not determine the origin of oocytes. They were only detected when measuring about $40 \mu \mathrm{m}$ in diameter, whereas the diameter of primary oocytes was reported to be between 10 and $15 \mu \mathrm{m}$ in previous studies of Hippospongia and Spongia (Tuzet \& Pavans de Ceccatty 1958; Kaye 1991; Baldacconi et al. 2007). At this stage, the hypothetical archeocyte or choanocyte origin of oogonia (Tuzet \& Pavans de Ceccatty 1958; Kaye 1991) remains to be thoroughly investigated.

The H. communis population in Kerkennah's shallow waters showed a consistent pattern in the timing of 


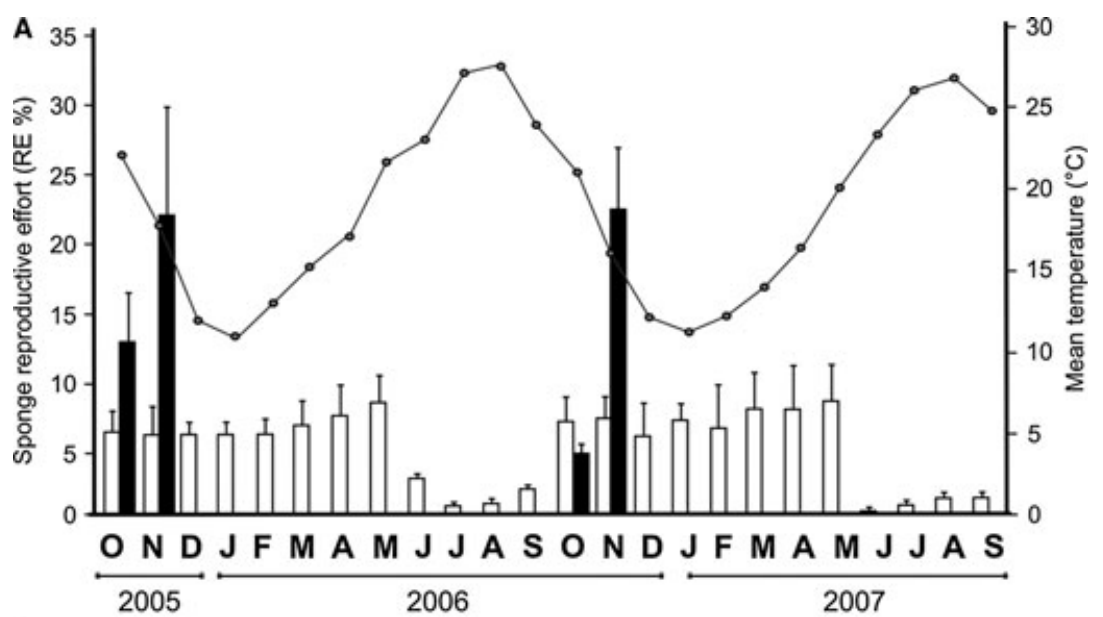

B

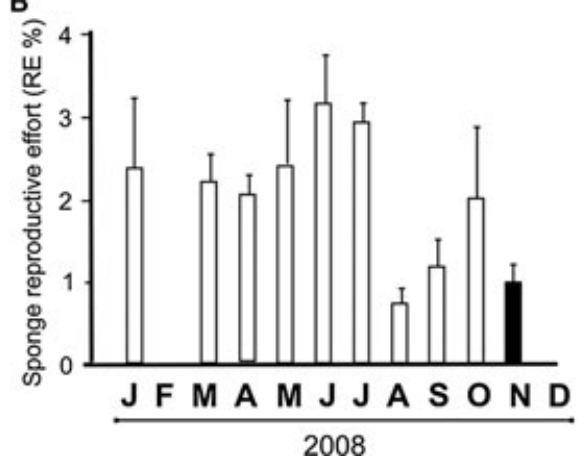

Fig. 5. Reproductive effort (RE) in H. communis of both populations: (A) mean RE in Kerkennah sponges over 2 years plotted versus SST; and (B) mean RE in Marseille sponges over 1 year. spermatogenesis, oogenesis, embryogenesis and larval development. However, the comparison of the reproduction patterns with the population from Marseille indicated slight differences in the timing of gametogenesis. It seems that spermatogenesis occurs at about the same time in the two regions but this needs to be confirmed by additional sampling in November in Marseille. Females are in the reproduction phase throughout the year, a given individual being able to develop young oocytes and to end larval development at the same time. Whichever the Mediterranean region considered in this study, oogenesis started in March and extended for 8-9 months at population level (Fig. 4). In temperate latitudes, populations of most brooding demosponges usually concentrate larval release in one annual period which can extend over several weeks, usually during the warm season (e.g. Wapstra \& Van Soest 1987; Maldonado \& Young 1996; Corriero et al. 1998; Maldonado \& Uriz 1998; Ereskovsky 2000; Mariani et al. 2000; Baldacconi et al. 2007). In our study, we observed a difference in the timing of larval release between the two locations: May and June at Kerkennah and July only in Marseille. Since fertilization seems to occur at the same time at the two sites, it is possible that embryogenesis is faster at Kerkennah than in Marseille, which may be explained by the difference in temperature regime. The time of larval release did not correspond to the period of highest seawater temperature, usually in August-September in the two regions. However, during our study, the first larvae were observed when seawater temperature reached $24^{\circ} \mathrm{C}$ and $22^{\circ} \mathrm{C}$, respectively, at Kerkennah and Marseille. Thus, the temperature regime may influence the reproduction of $H$. communis both by accelerating embryogenesis (faster in the warmest region) and by triggering larval release. It can also affect the RE, which is higher in Tunisia whatever the sex. In males from Kerkennah, more than $10 \%$ of the choanosome may be dedicated to the production of gametes, whereas it is limited to $1 \%$ in Marseille. Likewise, the annual average of RE for females from Kerkennah was about $5 \%$, whereas it was about $2 \%$ in Marseille.

Although temperature appears as a likely environmental cue for reproduction, it has been already demonstrated that other factors, such as exposure to light, can influence some aspects of reproductive cycles (Uriz et al. 1995; Maldonado \& Young 1996; Turon et al. 1998). Two of these Mediterranean studies assessed the influence of light on larval behavior and recruitment, two phases of the sponge life cycle that we did not consider in our study. Only Uriz et al. (1995) actually demonstrated that light exposure and resource bioavailability can affect the 

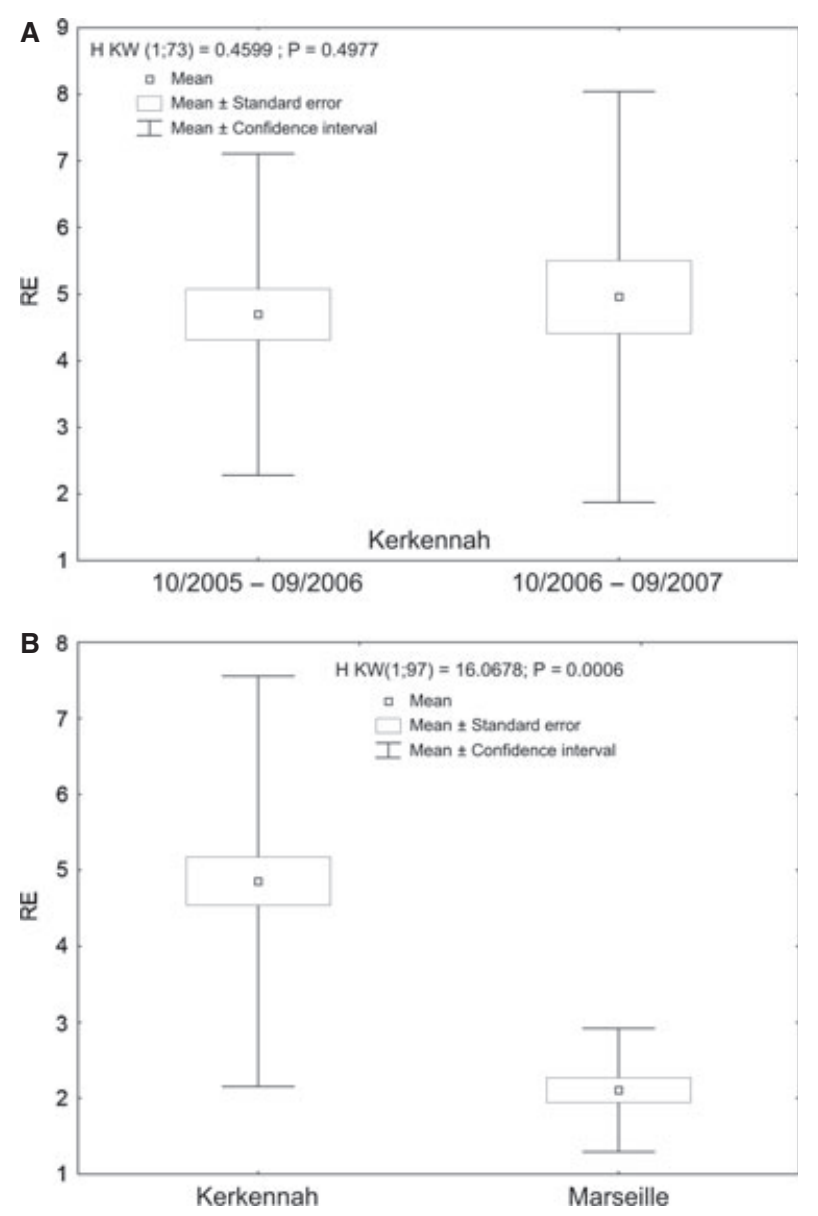

Fig. 6. Variation in time and space of reproductive effort (RE) for female $H$. communis: (A) comparison between 2 years at Kerkennah; (B) comparison between the two studied localities.

reproductive effort of the encrusting sponge Crambe crambe. Taking into account that another Mediterranean Spongiidae prefers to feed on photosynthetic microorganisms (cyanobacteria, nano- and pico-eukaryotes) rather than on bacteria (Topçu et al. 2010), we must consider that light intensity can act as a significant environmental forcing on $H$. communis reproductive effort. Few other studies investigated the environmental influence on reproductive processes of sponges from geographically distinct populations. Temperature and salinity (Witte et al. 1994; Corriero et al. 2004), food availability (Witte 1996; Spetland et al. 2007) and water turbidity (Whalan et al. 2007b) were among the factors assessed. Although only water temperature has been considered here, this work indicates that temperature can have a key role by controlling the reproductive strategy through timing and effort. In $H$. communis, the embryonic development seems to be faster under the warm conditions of Tunisia. Similar trends have been reported for the oogenesis of
Halichondria panicea and Tetilla sp. (Witte \& Barthel 1994; Witte et al. 1994; Meroz-Fine et al. 2005).

This study contributes to a better knowledge of the reproduction patterns, development features, seasonality and natural variability of reproductive efforts of a commercial sponge. However, further investigations on larval biology and recruitment of juveniles of $H$. communis will add to a comprehensive understanding of the population dynamics and to the design of a conservation plan for this over-harvested bath sponge. Investigating two populations living under contrasted temperature regimes has offered evidence for the possible influence of the environment on sponge phenology. In the context of global change of the Mediterranean Sea, which triggers drastic alterations of thermal regime and resource availability, we might expect an impact on the sponge's reproduction patterns at local scales. Do these biological responses constitute adaptive responses to the warming of the Mediterranean Sea? Does it mean that, because of the demonstrated warming trend in the northern basin, a higher reproductive effort will make $H$. communis more abundant? This may turn out to be the case if disease outbreaks related to climatic events do not severely threaten sponge beds throughout the Mediterranean Sea (Lejeusne et al. 2010).

\section{Acknowledgements}

We would like to thank the Tunisian National Institute of Marine Science and Technologies (Laboratory of Marine Biodiversity and Biotechnologies) for funding this study in Tunisia. This work was also partly supported by the following research programs: European Marie Curie Mobility program (fellowship of A. Ereskovsky, MIF1CT-2006-040065) and the ECIMAR project (ANR-06BDIV-001) of the French 'Agence Nationale de la Recherche'. In Tunisia, the authors warmly thank fishermen of Kerkennah, especially Mohamed Jaber, Chokri and their families, for their help in sampling and for their hospitality. In France, the authors are also grateful to Roland Graille and Bernard De Ligondes for their assistance at sea, to Chantal Bezac for her technical assistance with the histology, and to Nicole Boury-Esnault, Jean Vacelet and Pierre Chevaldonné for so many fruitful discussions and revision of the text.

\section{References}

Allemand-Martin M.A. (1906) Etude De Physiologie Appliquée A La Spongiculture Sur Les Côtes De Tunisie. Thèse Faculté Science, Lyon: 195 pp.

Ayling A.L. (1980) Patterns of sexuality: asexual reproduction and recruitment in some subtidal marine demospongiae. Biological Bulletin, 158, 271-282. 
Baldacconi R., Nonnis-Marzano C., Gaino E., Corriero G. (2007) Sexual reproduction, larval development and release in Spongia offcinalis L. (Porifera, Demospongiae) from the Apulian coast. Marine Biology, 152, 969-979.

Ben Mustapha K., Vacelet J. (1991) Etat actuel des fonds spongiferes de Tunisie. In: Boudouresque C.F., Avon M., Gravez V. (Eds), Les Espèces Marines À Protéger En Méditerranée. GIS Posidonie, Marseille: 43-46.

Bensoussan N., Romano J.C., Harmelin J.G., Garrabou J. (2010) High resolution characterization of northwest Mediterranean coastal waters thermal regimes: to better understand responses of benthic communities to climate change. Estuarine, Coastal and Shelf Science, 87, 431-441.

Bhaud M., Cha J.H., Duchêne J.C., Nozais C. (1995) Influence of temperature on the marine Fauna: what can be expected from a climatic change? Journal of Thermal Biology, 20, 91-104.

Chung I.F., Huang Y.M., Lee T.H., Liu L.L. (2010) Reproduction of the bath sponge Spongia ceylonensis (Dictyoceratida: Spongiidae) from Penghu, Taiwan. Zoological Studies, 49, 601-607.

Cook S.D.C., Bergquist P.R. (1999) New species of dictyoceratid sponges from New Zealand: Genus Ircinia (Porifera: Demospongiae: Dictyoceratida). New Zealand Journal of Marine and Freshwater Research, 33, 545-563.

Corriero G., Scalera Liaci L., Nonnis Marzano C., Gaino E. (1998) Reproductive strategies of Mycale contarenii (Porifera: Demospongiae). Marine Biology, 131, 319-327.

Corriero G., Longo C., Mercurio M., Nonnis Marzano C., Lembo G., Spedicato M.T. (2004) Rearing performance of Spongia officinalis on suspended ropes off the Southern Italian Coast (Central Mediterranean Sea). Aquaculture, 238, 195-205.

Crisci C., Bensoussan N., Romano J.C., Garrabou J. (2011) Temperature anomalies and mortality events in marine communities: Insights on factors behind differential mortality impacts in the NW Mediterranean. PLOS ONE, 6, e23814.

Dayton P.K. (1979) Observations of growth, dispersal and population dynamics of some sponges in McMurdo Sound, Antarctica. In: Levi C., Boury-Esnault N. (Eds), Colloques Internationaux Du C.N.R.S. Biologie des Spongiaires, 291: 271-282.

Dayton P.K., Tegner M.J., Edwards P.B., Riser K.L. (1998) Sliding scales, ghosts, and reduced expectations in kelp forest communities. Ecological Applications, 8, 309-322.

Ereskovsky A.V. (2000) Reproduction cycles and strategies of cold-water sponges Halisarca dujardini (Demospongiae, Dendroceratida), Myxilla incrustans and Iophon piceus (Demospongiae, Poecilosclerida) from the White Sea. Biological Bulletin, 198, 77-87.

Ereskovsky A.V. (2010) The Comparative Embryology of Sponges. Springer-Verlag, Dordrecht: 47-176.

Ettinger-Epstein P., Whalan S.W., Battershill C.N., de Nys R. (2007) Temperature cues gametogenesis and larval release in a tropical sponge. Marine Biology, 153, 171-178.
Fell P.E. (1974) Porifera. In: Giese A.C., Pearse J.S. (Eds), Reproduction of Marine Invertebrates. Academic Press, New York: 51-132.

Fell P.E. (1983) Oogenesis, oviposition and oosorption. In: Adiyodi K.G., Adiyodi R.G. (Eds), Reproductive Biology of Invertebrates, volume 1. John Wiley \& Sons,Chichester: $1-29$.

Fromont J. (1999) Reproduction of some demosponges in a temperate Australian shallow water habitat. Memoirs of the Queensland Museum, 44, 185-192.

Gaino E., Burlando B., Zunino L., Pansini M., Buffa P. (1984) Origin of male gametes from choanocytes in Spongia officinalis (Porifera, Demospongiae). International Journal of Invertebrate Reproduction and Development, 7, 83-93.

Gaino E., Pronzato R., Corriero G., Buffa P. (1992) Mortality of commercial sponges: incidence in two Mediterranean areas. Bolletino de Zoologia, 59, 79-85.

Gaino E., Baldaconi R., Corriero G. (2007) Post larval development of the commercial sponge Spongia officinalis L (Porifera, Demospongiae). Tissue and Cell, 39, 325-334.

Gaino E., Frine E., Giuseppe C. (2010) Reproduction of the intertidal sponge Hymeniacidon perlevis (Montagu) along a bathymetric gradient. Open Marine Biology Journal, 4, 47-56.

Garrabou J., Coma R., Bensoussan N., Bally M., Chevaldonné P., Cigliano M., Diaz D., Harmelin J.G., Gambi M.C., Kersting D.K., Ledoux J.B., Lejeusne C., Linares C., Marschal C., Pérez T., Ribes M., Romano J.C., Serrano E., Torrents O., Zabala M., Zuberer F., Cerrano C. (2009) A new large scale mass mortality event in the NW Mediterranean rocky benthic communities: effects of the 2003 heat wave. Global Change Biology, 15, 1090-1103.

Gerasimova E.I., Ereskovsky A.V. (2007) Reproduction of two species of Halichondria (Demospongiae: Halichondriidae) in the White Sea. In: Custódio M.R., Lôbo-Hajdu G., Hajdu E., Muricy G. (Eds), Porifera Research, Biodiversity, Innovation and Sustainability. Série Livros 28. Museu Nacional de Rio de Janeiro, Rio de Janeiro: 327-333.

Hoppe W.F. (1988) Reproductive patterns in three species of large coral reef sponges. Coral Reefs, 7, 45-50.

Kaye H.R. (1991) Sexual reproduction in four Caribbean commercial sponges. II. Oogenesis and transfer of bacterial symbionts. Invertebrate Reproduction and Development, 19, $13-24$.

Kaye H.R., Reiswig H.M. (1991a) Sexual reproduction in four Caribbean commercial sponges. I. Reproductive cycles and spermatogenesis. Invertebrate Reproduction and Development, 19, $1-11$.

Kaye H.R., Reiswig H.M. (1991b) Sexual reproduction in four Carribean commercial sponges. III. Larval behaviour, settlement and metamorphosis. Invertebrate Reproduction and Development, 19, 25-35.

Kinne O. (1970) Temperature - invertebrates. In Kinne O. (Ed.), Marine Ecology: A Comprehensive Integrated Treatise of Life in Oceans and Coastal Waters. London, New York, Sydney, Toronto, Willey Interscience: 407-514. 
Lejeusne C., Chevaldonné P., Pergent-Martini C., Boudouresque C.F., Pérez T. (2010) Climate change effects on a miniature ocean: the highly diverse, highly impacted Mediterranean Sea. Trends in Ecology and Evolution, 25, 250-260.

Leong W., Pawlik J.R. (2011) Comparison of reproductive patterns among 7 Caribbean sponge species does not reveal a resource trade-off with chemical defenses. Journal of Experimental Marine Biology and Ecology, 401, 80-84.

Lévi C. (1956) Etude des Halisarca de Roscoff. Embryologie et systématique des Demosponges. Travaux de la Station Biologique de Roscoff, 7, 3-181.

Maldonado M. (2006) The ecology of the sponge larva. Canadian Journal of Zoology, 84, 175-194.

Maldonado M., Riesgo A. (2008) Reproductive output in a Mediterranean population of the Homosclerophorid Corticium candelabrum (Porifera, Demospongiae), with notes on the ultrastructure and behavior of the larva. Marine Ecology, 29, 298-316.

Maldonado M., Riesgo A. (2009) Gametogenesis, embryogenesis, and larval features of the oviparous sponge Petrosia ficiformis (Haplosclerida, Demospongiae). Marine Biology, 156, 2181-2197.

Maldonado M., Uriz M.J. (1998) Microrefuge exploitation by subtidal encrusting sponges: patterns of settlement and postsettlement survival. Marine Ecology Progress Series, 174, 141150.

Maldonado M., Young C.M. (1996) Effects of physical factors on larval behavior, settlement and recruitment of four tropical demosponges. Marine Ecology Progress Series, 138, 169-180.

Mariani S., Uriz M.J., Turton X. (2000) Larval bloom of the oviparous sponge Cliona viridis: coupling of larval abundance and adult distribution. Marine Biology, 137, 783-790.

Mercurio M., Corriero G., Gaino E. (2007) A 3-year investigation of sexual reproduction in Geodia cydonium (Jameson 1811) (Porifera, Demospongiae) from a semi enclosed Mediterranean bay. Marine Biology, 151, 14911500.

Meroz-Fine E., Shefer S., Ilan M. (2005) Changes in morphology and physiology of an East Mediterranean sponge in different habitats. Marine Biology, 147, 243-250.

Pérez T., Garrabou J., Sartoretto S., Harmelin J.G., Francour P., Vacelet J. (2000) Mortalité massive d'invertébrés marins: un événement sans précédent en Méditerranée nordoccidentale. Comptes rendus de l'Académie des sciences. Série III, Sciences de la vie, 323, 853-865.

Pérez T., Ivanisevic J., Dubois M., Pedel L., Thomas O.P., Tokina D., Ereskovsky A.V. (2011) Oscarella balibaloi, a new sponge species (Homoscleromorpha: Plakinidae) from the Western Mediterranean Sea: cytological description, reproductive cycle and ecology. Marine Ecology, 32, 174187.

Reiswig H.M. (1973) Population dynamics of three Jamaican Demospongiae. Bulletin of Marine Science, 23, 191-226.
Reiswig H.M. (1983) Porifera: Spermatogenesis. In: Adiyodi K.G., Adiyodi R.G. (Eds), Reproductive Biology of Invertebrates. Volume 2. John Wiley \& Sons, Chichester: 1-21.

Riesgo A., Maldonado M. (2008) Differences in reproductive timing between sponges sharing habitat and thermal regime. Invertebrate Biology, 127, 357-367.

Riesgo A., Maldonado M., Durfort M. (2007) Dynamics of gametogenesis, embryogenesis, and larval release in a Mediterranean Homosclerophorid demosponge. Marine and Freshwater Research, 58, 398-417.

Sarà M. (1992) Porifera: sexual differentiation and behaviour. In: Adiyodi K.G., Adiyodi R.G. (Eds), Reproductive Biology of Invertebrates. Vol. 5. John Wiley \& Sons, Chichester: 1-29.

Scalera-Liaci L., Sciscioli M., Matarrese A., Giove C. (1971) Osservazioni sui cicli sessuali di alcune Keratosa (Porifera) e loro interesse negli studi filogenetici. Atti della Societa Peloritana di Scienze Fisiche Matematiche e Naturali, 17, 33-52.

Simpson T.L. (1984) The Cell Biology of Sponges. Springer, New York: 662 pp.

Spetland F., Rapp H.T., Hoffmann F., Tendal O.S. (2007) Sexual reproduction of Geodia barretti Bowerbank, 1858 (Porifera, Astrophorida) in two Scandinavian fjords. In: Custodio M.R., Lobo-Hajdu G., Hajdu E., Muricy G. (Eds), Porifera Research, Biodiversity, Innovation and Sustainability. Museu Nacional de Rio de Janeiro, Rio de Janeiro: 613-620.

Storr J.F. (1964) Ecology of the Gulf of Mexico Commercial Sponges and Its Relation to the Fishery. Special Scientific Report - Fisheries Vol 466. Dept. of the Interior, Bureau of Commercial Fisheries, Washington, DC, US: 1-73.

Topçu N.E., Pérez T., Gregori G., Harmelin-Vivien M. (2010) In situ investigation of Spongia officinalis (Demospongiae) particle feeding: coupling flow cytometry and stable isotope analysis. Journal of Experimental Marine Biology and Ecology, 389, 61-69.

Turon X., Tarjuel I., Uriz M.J. (1998) Growth dynamics and mortality of the encrusting sponge Crambe crambe (Poecilosclerida) in contrasting habitats: correlation with population structure and investment in defence. Functional Ecology, 12, 631-639.

Tuzet O., Pavans de Ceccatty M. (1958) La spermatogenèse, l'ovogenèse, la fécondation et les premiers stades du développement d'Hippospongia communis LMK. (= H. equina O.S.). Bulletin Biologique de France et de la Belgique, 92, 1-18.

Uriz M.J., Turon X., Becerro M.A., Galera J., Lozano J. (1995) Patterns of resource allocation to somatic defensive, and reproductive functions in the Mediterranean sponge Crambe crambe (Demospongiae, Poecilosclerida). Marine Ecology Progress Series, 124, 159-170.

Vacelet J. (1994) The Struggle against the Epidemic Which is Decimating Mediterranean Sponges, Technical Report. FAO, Rome, 39pp.

Vacelet J., Verdenal B., Perinet G. (1988) The iron mineralization of Spongia officinalis L.(Porifera, Dictyoceratida) and its relationships with the collagen skeleton. Biology of the Cell, 62, 189-198. 
Wapstra M., Van Soest R.W.M. (1987) Sexual reproduction, larval morphology and behaviour in Demosponges from the southwest of the Netherlands. In: Boury-Esnault N., Vacelet J. (Eds), Taxonomy of Porifera. NATO ASI Series Vol. 13. Springer, Berlin: 281-307.

Whalan S., Battershill C., de Nys R. (2007a) Sexual reproduction of the brooding sponge Rhopaloeides odorabile. Coral Reefs, 26, 655-663.

Whalan S., Battershill C., de Nys R. (2007b) Variability in reproductive output across a water quality gradient for a tropical marine sponge. Marine Biology, 153, 163-169.

Wing S.R., Botsford L.W., Morgan L.E., Diehl J.M., Lundquist C.J. (2003) Inter-annual variability in larval supply to populations of three invertebrate taxa in the northern California Current. Estuarine, Coastal and Shelf Science, 57, 859-872.

Witte U. (1996) Seasonal reproduction in deep-sea sponges triggered by vertical particle flux? Marine Biology, 124, 571586.

Witte U., Barthel D. (1994) Reproductive cycle and oogenesis of Halichondria panicea (Pallas) in Kiel Bight. In: van Soest R.W.M., van Kempen T.M.G., Braekman J.C. (Eds), Sponges in Time and Space. Balkema, Rotterdam: 297-306.

Witte U., Barthel D., Tendal O. (1994) The reproductive cycle of Halichondra panicea Pallas and its relationship to temperature and salinity. Journal of Experimental Marine Biology and Ecology, 183, 41-52. 